\title{
INSIDER INSIGHTS ABOUT EDUCATIONALPROVISIONS FOR CHILDREN IN CONFLICT WITH THE LAW IN CORRECTIONAL CENTRES IN GHANA
}

\author{
Dr. Lilian Ayete-Nyampong \\ Commission on Human Rights and Administrative Justice, Accra-Ghana \\ Email: layete14@yahoo.com
}

\begin{abstract}
Based on two years' of ethnographic fieldwork, this paper discusses gaps in educational provisions for children in conflict with the law in correctional centres in Ghana. Educational activities permeate the entire fabric of correctional institutions for children in conflict with law. These activities play a vital role, and per correctional authorities, contribute to the reformation of these juvenile and young offenders. Notwithstanding institutional efforts to promote educational efforts, ethnographic evidence points to educational provisions being confronted with a lack of interest by youngsters as well as pedagogical, gender and structural gaps. A key highlight of this paper is the fact that children in conflict with the law, amidst such constraints, demonstrate the capacity to side track from, as well as institutionally accepted methods by devising their own seemingly crude ones. These appropriated crude methods, though run counter to the institutionally accepted ones, nevertheless yield useful outcomes. Though, based on a small-scale ethnographic research that does not lend itself to generalisations, discussions reveal relevant insider insights that unearth gaps in educational provisions previously concealed from human rights monitors. Within the grip of confinement, coupled with educational constraints, youngsters demonstrate the capacity to contribute to their own processes of change and development. Discussions draw on an anthropological research conducted from 2008 to 2013 with children in correctional institutions in Ghana, providing first-hand data complementary to most human rights and legal studies. Methods such as life history narratives, participant observations, interviews and also focus group discussions were employed.
\end{abstract}

Keywords: Appropriation, Children in Conflict with the Law, Correctional Centres, Educational Gaps, Ghana.

\section{Introduction}

This research, upon which this paper is based, was conducted at junior and senior correctional centres for juvenile and young offenders in Ghana from 2008 to 2013. A juvenile offender is a child under the age of 18 who is in conflict with the law and has been convicted of an offence in keeping with Ghana's Juvenile Justice Act of 2003 (GOG, 2003). A young offender is 18 years or more, but below 21years and has been convicted of an offence. The Juvenile Justice Act refers to both juvenile and young offenders as children in conflict with the law.

The Senior Correctional Centre (SCC), the only one in Ghana primarily holds young male offenders but additionally, in accordance with the Juvenile Justice Act, houses juvenile male offenders who have committed serious crimes. The Junior Correctional Centre (JCC), also the only functional one in Ghana, holds female juvenile offenders. The SCC and the JCC are both located in Accra, the capital city of Ghana and hold most children in conflict with the law in Ghana, given that only one SCC and one JCC exists for boys and girls in Ghana. 
Prior to committal or admission to these centres, youngsters are already aware of the educational function of correctional centres deriving from their sentence which states that youngsters are committed to acquire educational skills for reformation purposes. Education; therefore, plays a key role in correctional centres and is highly esteemed by staff and most youngsters. Approximately $80 \%$ of each day, apart from weekends are committed to these activities. Interviews and participant observations of youngsters depict that institutions pride themselves on the educational attainments of youngsters and do not hesitate to conduct visitors around their classrooms to observe lessons. Youngsters who pass their national examinations are also cited when reference is made to the achievements of the institution and such youngsters constitute evidence of reform and correction. Possessing a Basic Education Certificate Examination (BECE) or a West Africa Senior School Certificate Examination (WASSCE) also constitutes a status symbol for most youngsters. Male youngsters in possession of BECE or WASSCE certificates rise to the level of teachers who teach other youngsters.

Notwithstanding the sense of pride that institutions derive from educational attainments, empirical evidence of my research reveal that educational activities are plagued by lack of interest as well as pedagogical, gender and structural and gaps (Ayete-Nyampong, 2013). My employer, the National Human Rights Institution, the Commission on Human Rights and Administrative Justice (CHRAJ) is constitutionally mandated to visit and inspect conditions and facilities at correctional centres for juvenile and young offenders to ensure conformity with relevant standards. It is worth noting that whereas questionnaire employed monitors of the CHRAJ have in the past sought information on educational provisions in correctional centres in Ghana, responses have had no indications of such gaps (CHRAJ, 1986-2010).I, as well as other monitors, might have been blinded to such views possibly due to the structured methods employed and the brief duration of such visits which could not yield much in terms of the lived-in experiences of youngsters.

\section{Review of Relevant Literature}

Studies on juvenile justice identified for Africa are relatively few. South Africa is credited with a high proportion of these studies in the areas of HIV/AIDS in prisons and correctional centres (Gaum, Hoffman, \& Venter, 2006); diversion programmes (Cupido, Kritzinger, \& Van Aswegen, 2005); sexual violence, youth gangs and child soldiers (Petersen, Bhana, \& McKay, 2005; Steinberg, 2004). Other studies are identified on sentencing policy for juvenile offenders (Howes, 1993), criminal accountability and rights of children in South Africa (Pillay, 2006) and countries such as Sierra Leone and Rwanda (Arts \& Popovski, 2006). Most of these studies are survey based. Such survey-based studies aim at formal penal and criminal justice reform and are not well situated within the context of everyday prison or correctional practices.

Ethnographic field studies in Africa's prisons and correctional institutions are scanty. These arch by De Kock (2005) on youth in conflict with the law examined life stories of young people awaiting trial in Gauteng, South Africa, but it does not include young offenders in detention. Jefferson (2007) in an eight-month ethnographic field study on prison officers' training and practice in Nigeria, examined penal philosophy and practice of the Nigerian Prisons Service. Lindegaard (2009)did some work on male gangsters in Cape Town. Similarly, Sauls (2009) researched violence and the daily management of children in a place of safety in Cape Town.

Generally, literature on African youth as social actors (Abebe \& Kjorholt, 2009; Christiansen, 2006; Christiansen, Utas, \& Vigh, 2006; Honwana \& De Boeck, 2005; Omoniyi, Scheld, \& Oni, 2009; Peters, 2006) is mostly preoccupied with 'free youth' in contexts of war, conflict, violence and politics and seldom about confined youth as social actors. Confined youngsters are either presumed to be isolated from wider socio-economic or cultural processes or are considered incapable of negotiating the boundaries of confinement 


\section{Methods}

The research upon which this paper is based is the first ever that involved a practitioner assuming the status of a researcher in a confinement site for children in conflict with the law. The research employed a total of 185 interviews (90 at the JCC and 95 at the SCC), 116 participant observations ( 51 at the JCC and 65 at the SCC) at both institutions and held 30 focus group discussions ( 15 at each institution).

I pay tribute to officers in charge of the correctional centres as well as the oversight authority of the correctional centres who provided access to the institutions as well as to the young and juvenile offendersi. The many years of collaboration between my employer, the national human rights institution in Ghana, namely, the Commission on Human Rights and Administrative Justice (CHRAJ) and these oversight institutions also facilitated access to these institutions.

My research status involved negotiating a shift from my practitioner experience in human rights monitoring that drew from epistemological approaches which sought an absolute truth by means of generalizations and statistical representations. Stemming from this methodological stance, I could not employ a definite set of questions, as was the case during previous visits to detention institutions associated with my practitioner status. On the contrary, I primarily avoided the idea of developing a fixed set of questions. My researcher approach; therefore, differed significantly from my practitioner approach where structured questions around pre-arranged agendas were prepared ahead of visits to detention institutions. The research was not based on hypothesis testing, but required that the research process and my research role be guided by emergent empirical data. While this inductive approach is often characterised by serendipity and was exciting given the surprises associated with it, it was also marked by insecurity and powerlessness experienced by both the researcher and the researched. Distinct boundaries were not set and one could not clearly predict the next step nor strategize ahead in terms of what methods to employ (Ayete Nyampong, 2015). The power that I enjoyed as a human rights practitioner from the presentation of questionnaires, as well as subsequent discussions that ensued about compliance or non-compliance with various human rights standards seemed lost in the new process.

Rigidly sticking to the demands of my practitioner role or insider grounding, adhering to some set rules or blueprints, would have deprived me of the required capacity for reflexive analysis. Such reflexive analysis involves being able see with both sets of eyes, that of a practitioner as well as a researcher. Yet, it also demands being able to make some distinction between diverse positions and not to amalgamate such positions, however entangled they may seem. I tried to manage these positions by stepping back from my acquaintance and familiarity afforded me by my practitioner grounding, and yet not stepping back entirely away from the scene.

\section{Findings}

\section{Pedagogical gap and lack of interest}

At the SCC, all youngsters upon admission who have attained some level of formal education can advance their education. Youngsters are assessed upon entry to determine the appropriate level of placement and are placed in various classes depending on their level of education. By enrolling in formal education, youngsters follow the designated national curriculum and syllabus as well as sit national certificated examinations such as the BECE and the WASCE for senior high schools as well as the National Vocational Training Institute exams (NVTI).

Notwithstanding the institution's commitment to support educational provisions, staff members have expressed concerns during interviews and focus group discussions, about youngsters' lack of interest in formal educational lessons. One officer stated: 
These children do not seem interested in their lessons, only about three out of ten do. With all the efforts we put in, the boys show little interest and they have to be forced and coaxed sometimes in order to show some seriousness; this makes our work difficult (AyeteNyampong, 2013, p. 80)

Participant observations also reveal that youngsters demonstrate little interest in formal lessons and must be coaxed to attend. My observation of formal educational lessons show that most classes are not interactive; teachers lectured most of the time with little eye contact and some students comfortably placed their heads on their tables and slept (AyeteNyampong, 2013, p. 136). Interviews and focus group discussions reveal that most youngsters were out of school for a considerable length of time prior to committal to correctional centres and have not been acquainted with a rigid formal programme of education for some time.

\section{Gender gap}

There is no provision of formal certificated education at the girls' institution. Girls who attain some level of formal education before committal are unable to further their education while in detention. Yaa, a female youngster was qualified for admission to Senior High School at the time of committal; however, there was no opportunity for her to advance her formal education during the period she was in detention or committal. Though she participated in all the types of vocational training offered and had acquired useful skills, her formal education was seriously hampered. By the time Yaa had served her sentence, her BECE certificate was already five years old and was reportedly not accepted by the schools she had approached for admission. This required that she went back three years to start junior high school all over again. She was keen to do so, but the timing of the academic year did not coincide with the period she was discharged from the centre. Later, she reportedly resorted to being an apprentice at a hair dressing salon. In my final conversation with her at the time of discharge, she sounded very disappointed and shed tears, for though she was still interested in continuing her formal education and looked forward to becoming a chartered accountant, there was little hope of achieving this goal (Ayete-Nyampong, 2013, p. 137).

Further, Vocational and Technical Education (VTE), like formal education at the boys' institution is a standardized programme and assessed by a national body. Male youngsters are trained to sit for National Vocational Training Institute (NVTI) examinations which qualify them for jobs or further education such as the Higher National Diploma (HND). Contrastingly, VTE for girls is un-certificated and not assessed based on national examinations(Ayete-Nyampong, 2013, p. 138). Girls are only sometimes awarded certificates of participation which do not promote their prospect for education or job acquisition upon discharge from the correctional centre.

\section{Structural gap}

In accordance with the Juvenile Justice Act 653 of 2003, section 23 (GOG, 2003), juveniles who upon arrest are not released on bail, receive a court order either for committal to the care of parents, close relative or anyone willing to take care of juvenile, or to be remanded in state custody. Upon arrest, juveniles must be sent to places of safety or remand homes within 48 hours of arrest (section 14). It was observed in contravention of this provision of the Juvenile Justice Act, that youngsters are kept in police custody for as long as one and a half years (Ayete-Nyampong, 2013). During this prolonged period, no formal educational provision is made for youngsters.

Youngsters, upon committal, are expected to undergo a mandatory minimum period of observation of six months. In practice, the period of observation usually lasts for a year and it is only after this period that youngsters can engage in vocational training and workshops. In other words, newly admitted youngsters are unable to benefit from educational provisions. Richard was one of such youngsters. He states: 'I did not learn any vocation as my sentence was I year' (Ayete-Nyampong, 2013, p. 139). Thus, newly admitted youngsters such as Richard, are unable to participate in VTE lessons as they are virtually kept under lock for the entire day after non-formal lessons. 
The empirical evidence of my research points to the existence of significant pedagogical, gender and structural gaps. Denying girls and newly admitted youngsters the opportunity to attain or advance formal certificated education is a significant oversight which has disadvantaged numerous boys and girls already and which requires urgent and immediate attention.

\section{Agentic youngsters: The case of an inmate teacher}

Non-formal lessons at the SCC are tailored to the needs of boys of low educational background and they are not certificated. The focus is on the acquisition of basic literacy and numeracy skills. I observed a non-formal class taught by an inmate teacher, namely William, who actively engaged the interest of his class.

William's class was lively and usually elicited mass responses (one could hear loud responses far off). He also gave attention to individual youngsters and made sure that each student tried to read. William frowned on anyone who could not read and was sensitive to whisperings, comments and movements. William taught the English and the twi(a Ghanaian language spoken by most youngsters) alphabet in such a way that almost every single person in the class could pronounce the alphabet and draw the letters. He then followed it with two letter words and soon the class started reading out and writing three letter words. Later, he introduced short recitals that contained two and three letter words and the class with little difficulty recited without having to commit recitals to memory. Lessons did not follow any uniform syllabus or timetable and William carried out his work independently without much supervision though an officer usually sat with the inmates, while he taught. By keeping a cane by his side, William like other inmate teachers, keep their classes active, alert and their students seldom doze off; also, anyone who scorns or teases the other is caned.

William was in full control of the class and when he called someone to respond to a question and the person did not do so promptly he would say 'is that not your name or did you pick your name from the police station?'(Ayete-Nyampong, 2013, p. 142). Whenever he asked this question I thought it was merely an attempt to incite laughter to bring the class to order or raise alertness. The question however carried a further meaning. I gathered from interviews with youngsters as well as focus group discussions that some of them changed their names and ages prior to committal at the point of arrest. Thus, there was a possibility for such youngsters not to respond to these new names, probably because they had forgotten that they bore these names.

\section{Discussions}

My empirical evidence points to the existence of a marked gender gap. Denying girls the opportunity to attain or advance formal certificated education is a significant oversight which has disadvantaged numerous girls already. These above deficiencies are further hindered by the lack of a correctional centre for young female offenders. Whereas junior male recidivists or repeat offenders have a second chance at the SCC to further their education, female recidivists have no alternative than adult prisons.

My research establishes that children may not be interested in formal educational lessons because of the methods employed. Despite this lack of interest, such children manage to adapt and appropriate educational instructions for their own interest. This is in keeping with the development concept of side tracking and appropriation utilized by Olivier de Sardan (2005). Side-tracking, according to Olivier de Sardan (2005), is a way by which target groups 'appropriate' a project. Appropriation is the end sought by development operations, and yet it assumes shaping or re-reshaping the project in ways that run counter to the project's objectives and methods. Similarly, in correction institutions, inmates' objectives tend to correspond to the objectives of institutions in terms of educational provisions. Whereas youngsters demonstrate a clear lack of interest in formal lessons, some youngsters cherish educational certificates and seldomly admit during interviews their lack of interest. Thus, youngsters tend take upon themselves institutional goals of education. Participant observation, revealed that youngsters managed to shape and re-shape methods of delivery, 
thereby devising their own ways in line with their interests. William's case depicts the capacity of youngsters to adapt and appropriate educational methods that are in line with their own familiar experiences though tend to run counter to methods employed by officers. He employed crude methods such as caning youngsters, yet these methods nonetheless commanded the interest of youngsters and yielded useful outputs evidenced by their reading skills.

Based on foregoing discussions, this paper gives recognition to youngsters as social actors (Long, 2001) capable of influencing everyday experiences in committal. Scholarly work on African children and youth as social actors (Abebe \& Kjorholt, 2009; Christiansen, 2006; Christiansen et al., 2006; Honwana \& De Boeck, 2005; Omoniyi et al., 2009; Peters, 2006) is mostly preoccupied with 'free youth' in contexts of war, conflict, violence and politics.

This paper; therefore, offers a useful contribution to scholarly work on confined children as social actors from an actor oriented perspective. The term actor-oriented is preferred to actor-centred(Arce \& Long, 2007) given the former term's appropriateness to allow for the constitution of social actions within a range of contextual circumstances. It is a counterpoint of structural analysis in development sociology (Long, 2001) which does not treat young and juvenile offenders as a homogenous group, hampered by structural constraints. On the contrary, it recognizes the efforts of juvenile and young offenders as social actors in contributing to any change concerning them. A social actor in this respect is not merely a synonym for an individual, nor is it a fixated social category such as social class or gender, but it is a social construct. Thus, correctional institutions, social workers, prison officers, practitioners and policy makers are examples of social actors to whom agency can be attributed. Agency, in this regard, attributes to the individual actor, the capacity to process social experience and to devise ways of coping with life even under challenging circumstances in detention.

\section{Conclusion}

Gaps evident in educational provisions provide a different dimension to CHRAJ's reports which have been silent on gaps that my research has highlighted. The inside out approach of this research brings forward structural inequalities, children's lack of interest, as well as everyday nuances at correctional centres for children in conflict with the law.

Complementarities between my practitioner and researcher roles, notwithstanding the epistemological differences, have contributed to being able to access institutions and youngsters, as well as unearth concealed views.

This paper, though based on a small-scale research that does not lend itself to generalisations, nevertheless underscores the relevance of ethnographic approaches as well as insider insights for boys and girls in conflict with the law in committal. Such approaches in contrast to surveys, ensure that concealed aspects of confinement life are brought to light and that confined children benefit maximally from correctional that match their specific contexts and draw on their own resources and appropriated efforts. 


\section{References}

i. Abebe, T. \& Kjorholt, A., 2009. Social Actors and Victims of Exploitation: Working children in the cash in the cash economy of Ethiopia South. Childhood, 16(2), pp. 175-194.

ii. Arce, A. \& Long, N., 2007. Forging a New Anthropology of Development: Common Ground and Contentious Issues . In: A. Arce \& N. Long, eds. Paris: Karthala.

iii. Arts, K. \& Popovski, V., 2006. International Criminal Accountability and the Rights of Children, The Hague: Hague Academic Press..

iv. Ayete-Nyampong, L., 2013. Entangled Realities and Underlife of a Total Institution, Wageningen: Wageningen University.

v. CHRAJ, 2010. Annual Reports of the Commission on Human Rights and Administrative justice. Accra: CHRAJ.

vi. Christiansen, C., 2006. Youth, Religiosity and the AIDS Pandemic. Faith Friends and Family Virtues in Uganda. Dakar: Youth and the Global South.

vii. Christiansen, C., Utas, M. \& Vigh, H., 2006. Introduction. Navigating Youth, Generating Adulthood: Social Becoming in an African Context. Uppsala: Nordiska Afrikainstitutet.

viii. Cupido, M., Kritzinger, A. \& Aswegen, F. V., 2005. The Implementation of a Diversion Programme for Juvenile Offenders: Problem areas and 'pitfalls'. Social Work. s.l.:s.n.

ix. Gaum, G., Hoffman, S. \& Venter, J., 2006. Factors that influence adult recidivism: An exploratory study in Pollsmoor prison. South African Journal of Psychology, 36(2), pp. 407424 .

x. Honwana, A. \& Boeck, F. D., 2005. Makers and Breakers. Children and Youth in Postcolonial Africa Dakar. Dakar: CODESRIA.

xi. Howes, M., 1993. Social Skills Training as a Sentencing Option for Juvenile Offenders: The Cape Peninsula Juvenile Sentencing Project. Sosiale vaardigheidskoling as strafopsie vir jeugoortreders: die Skiereilandse jeugstrafprojek, 29(4), pp. 371-379.

xii. Jefferson, A., 2007. Prison Officer Training and Practice in Nigeria: Contention, Contradiction and re-imagining Reform Strategies. Punishment and Society, 9(3), pp. 253-269.

xiii. $\quad$ Kock, D. D., 2005. Youth in Conflict with the Law and Socio-Economic Experiences in Their childhood: A relationship. Journal of Child and Youth Care Work, Volume 20, pp. 56-71.

xiv. $\quad$ Lindegaard, R., 2009. Coconuts, Gangsters and Rainbow Fighters. How male youngsters navigate situations of violence in Cape Town, South Africa, Amsterdam: University Of Amsterdam.

xv. Long, N., 2001. Development Sociology: Actor Perspectives, London: Routledge.

xvi. Nyampong, L. A., 2013. Changing Hats: Transiting between Practitioner and Researcher Roles. In: E. R. \&. S. J. H. Drake Deborah, ed. The Palgrave Handbook of Prison Ethnography. Hampshire: Palgrave Macmillan, pp. 307-325.

xvii. Omoniyi, T., Scheld, S. \& Oni, D., 2009. Negotiating Youth Identity in a Transnational Context in Nigeria. Social Dynamics, Volume 35, pp. 1-18.

xviii. Petersen, I., Bhana, A. \& McKay, M., 2005. Sexual Violence and Youth in South Africa: The Need for Community-based Prevention Interventions. Child Abuse and Neglect, 29(11), pp. $1233-1248$. 
xix. $\quad$ Peters, K., 2006. Footpaths for Reintegration; Armed Conflict, Youth and the Rural Crisis in Sierra Leone. Wageningen: Unitversiteit van Wageningen.

xx. Pillay, A., 2006. Criminal Capacity in Children Accused of Murder: Challenges in the Forensic Mental Health Assessment. Journal of Child and Adolescent Mental Health, 18(1), pp. 17-22.

xxi. Sauls, H., 2009. Delinquency or Resilience? How Interpretations of Violence Translate Into the Daily Management of Children in a Place of Safety in Cape Town. Cape Town: s.n.

xxii. Steinberg, J., 2004. One Man's Search for Identity in the Cape Underworld and Prison gangs.. Johannesburg: Johannesburg: Jonathan Ball. 